\title{
Rational and Emotional Communication in Advertising in Women's Magazines in Brazil
}

\author{
Edward Robinson Marin ${ }^{\dagger}$ \\ UNIESP \\ Nadia Kassouf Pizzinatto ${ }^{\Omega}$ \\ Universidade Metodista de Piracicaba \\ Antonio Carlos Giuliani ${ }^{¥}$ \\ Universidade Metodista de Piracicaba
}

\begin{abstract}
This article investigated the incidence of rational and emotional arguments in messages from 5.536 advertisements of six women's magazines in Brazil (Claudia, Nova, Estilo, Marie Claire, Elle and Gloss), published between May / 2008 and August / 2009. The methodology was based on an exploratory study, supported on a scale of 14 items, by Resnik and Stern (1977), which recommend matching appeals to attitude toward the product, that is, use informative advertising, based on rational appeals for products in which the consumer attitude is predominantly cognitive. To assess the emotional content, we used the scale of eight items of Plutchik (1980), represented by the primary emotions - Anger, Fear, Sadness, Disgust, Surprise, Curiosity, Acceptance and Joy. Data analysis included the frequency of the two appeals in the general category (durables, non-durables and services), product, and correspondence analyzes were used to identify the prevalence of two types of arguments in selected magazines. The results show the concentration of ads on non-durable goods, followed by the category of services, that overcomes the advertisings on durables. The study also analyzes the incidence of emotional and rational arguments by product category and by magazine.
\end{abstract}

Keywords: Marketing. Advertising. Media. Magazines. Rational and emotional appeals.

Received on February 13, 2013; reviewed on July 26, 2013; accepted on November 04, 2013; disclosed on November 27, 2014.

* Author for correspondence:

${ }^{\dagger}$. MASTER by the University NOVE DE JULHO-UNINOVE, Institution: Professor at the University DRUMMOND and UNIESP Address: Rua General Osório, São Caetano do Sul - SP - Brazil E-mail:

edward.robinson.marin@mail.com Telephone: (11) 42283470

\footnotetext{
${ }^{\Omega}$ Doctorate in Business Administration from the School of Business Administration of São Paulo, of Fundação Getúlio Vargas (EAESP / FGV)

Institution: Professor in PPGA - Postgraduate Programme in Administration, Doctorate in Administration from the Universidade Metodista de Piracicaba - Unimep

Address: Rua Samuel Neves,Jardim Europa, Piracicaba - SP - Brazil

E-mail:nkp@nadiamarketing.com.br

Telephone: (19)34333437
}

\author{
${ }^{¥}$ Doctorate in Education from \\ Universidade Metodista de \\ Piracicaba - UNIMEP \\ Institution: Coordinator and \\ Professor of PPGA- Postgraduate \\ Programme in Management, \\ Doctorate in Administration in \\ Universidade Metodista de \\ Piracicaba- UNIMEP \\ Address: Rua Ipiranga, Centro - \\ Piracicaba - SP - Brazil \\ E-mail: cgiuliani@unimep.br \\ Telephone: (19) 31241560
}




\section{INTRODUCTION}

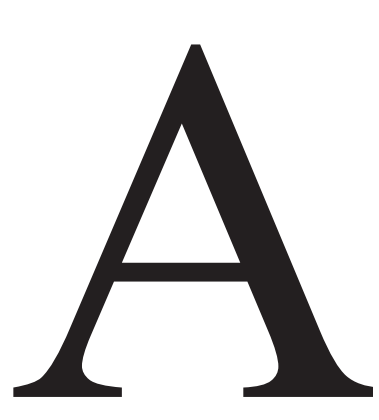

s markets are increasingly fragmented, marketing professionals are seeking new alternatives to identify the best segments and communicate effectively through them. According to Chiusoli et al. al. (2009), a segment that has grown exponentially is to consumer women now account for $85 \%$ of decision-making on purchases. Even the predominantly male labour market, started to live with the heterogeneity and stared naturally the feminine presence, informs Xavier (1998:77).

The greater participation of women in social context, labour and business market, highlight by Fraga and Serralvo (2006), has led to a change of role, transforming them into influential or marginal participants in the buying process to characters with higher presence in all decisionmaking stages of the purchase. Thus, with the rising of women as a highly interesting market segment, companies have found themselves forced to reshape their sales strategies and to the development of their products, adapting to this new reality (DEL-VECHIO; ANDRADE; BRONEMANN, 2007).

This reformulation affected the communication area, leading entrepreneurs trying to reach women also through advertisements in women's magazines. This mean of mass communication is an important vehicle for the insertion of advertising messages directed to that specific segment. In the insertion of advertising for different products aimed at that audience, advertisers take in some of them, messages of rational content and others messages of emotional content, assuming that the female segment is more susceptible to one and another message profile. What would be the trends, by product category, of the assumption of rational and emotional content, in advertising messages aimed at the female audience?

In summary, the research profile of advertisements for different product categories and assuming as methodology the content analysis in 5.536 advertisements of the six major Brazilian women's magazines, the main objective of the study was based on a research on how advertisers assume the female behaviour is: more susceptible to rational or emotional arguments.

\section{THEORETICAL REFERENCES}

\subsection{THE EFFECTIVENESS OF ADVERTISING IN WOMEN'S MAGAZINES}

Advertising in magazines is considered one of the main tools of the marketing mix, to communicate and to differentiate products from competitors. However the terms of advertising and propaganda are used with a different meaning. For this reason, in this work, 
we adopted the term advertising, in reference to the ads, according to Malanga (2008), for whom advertising is more persuasive, with well defined business purpose and is characterized as the art of awakening of the consumers' purchase desire. To the author, propaganda is a set of techniques of individual action, used to promote accession to a given ideological system (political, social or economic), while advertising is a set of techniques for collective action, in the sense used to promote the profit of a commercial activity. Shimp (2002) also argues that it is through advertising and other marketing tools that professionals work with the purpose of inducing the consumer to develop positive behaviour on the supply of goods and services.

Jorge (2008) in a work on the effectiveness of advertising in women's magazines, points out that it has a fundamental role in assigning a symbolic meaning to consumer goods and is part of social and cultural life. The author also points out that such widespread influence in society has attracted many researchers willing to prove that advertising is a powerful ideological force in consumer culture. In her view, over the past few years, women took their place in the labour market. In agreement, Russo and Troiano (2008) claim that women have great influence in making purchasing decisions for household or personal use products.

Accompanying these social and economic movements, women's magazines were part of the social and economic movements, as in its relationship with advertising, readers have been guiding to build their identity through means of a segmented consumption. Consequently, women's magazines are part of a group communications that are intended to govern the consumer's identity. The consumer can not, however, cease to be influenced by the behaviour and advertising. Women's magazines, like other popular media, constitute a field in which the financial interests certainly exert considerable power in the audience, and consumers are able to establish significant cultural and life standards.

However the effectiveness of advertising in women's magazines also depends on the effectiveness of the messages' arguments, which can rely on rational and emotional appeals. Therefore, it is necessary to consider them as an important factor in advertising strategy.

\subsection{EMOTIONAL APPEALS AS STRATEGY IN ADVERTISING}

Research in the areas of marketing have sought to understand the emotional aspects involving consumers in relation to consumption of products or services, as well as studying, generally, the influence of these features in the formation of consumer behaviour. They emphasize that, marketers are increasingly making use of emotional appeals in advertising, trying to establish a relationship of feeling, as they convey a sense of consumer satisfaction (HAWKINS et al, 2007, p. 192). Solomon (2002, p. 195) found that "many companies have 
turned to a more targeted strategy to emotional aspects, after realizing that consumers do not see many differences between brands, especially those that fall into the categories of established and mature assets". When used, the emotional appeal is able to generate satisfaction, or rather a sense of well being, becoming closer the relationship between advertising and consumer. Emotional appeals, unlike the informative or rational, according Man So (2004), are based on the experiential aspect of consumption. Therefore, they are widely used in advertising focusing towards the female audience, and it is believed to have positive effects on the consumers' reactions to advertising. For Sheth, Mittal and Newman (2001, p. 338), "emotions are aware of the occurrence of some physiological arousal followed by a behavioural response, along with the evaluation of the significance of both. This definition implies that emotions have three components: physiological, behavioural and cognitive". Plutchik (2003) argues that this definition can be seen as a first approximation of a consensual definition of emotions. Figure 1 shows the basic emotions and latent emotions in attachment points. The dyad formed by emotion Joy and the emotion Anticipation is called Optimism, and so on for the others.

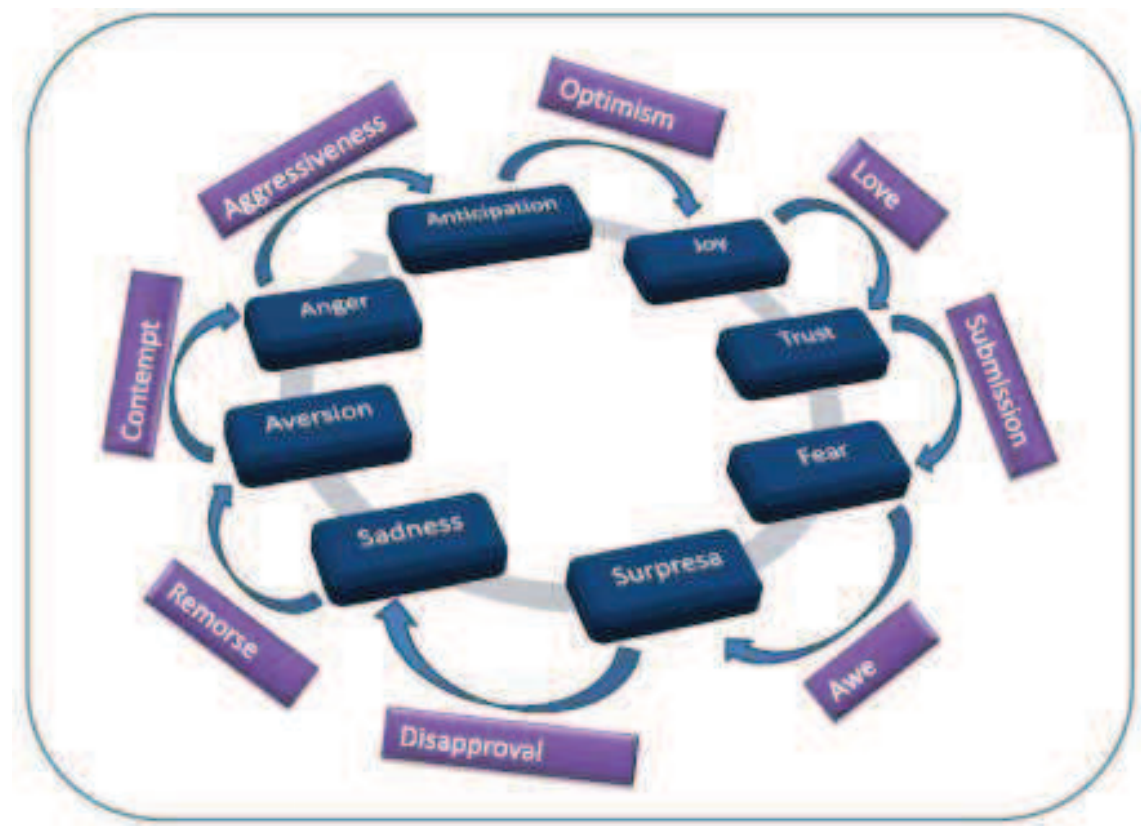

Figure 1 - Plutchik's characterization of the eight primary emotions Source: adapted from Plutchik (1980).

These eight human reactions are based on the evolutionary process and, according to Plutchik (1980), are the basic human emotions. Therefore, they are denominated primary emotions. But according to Sheth, Mittal and Newman (2001, p. 340), each of the eight primary emotions can vary in intensity: a) Fear - ranging from apprehension to terror. b) Anger - ranging from annoyance to rage. c) Joy - ranging from serenity to ecstasy. d) 
Sadness - ranging from pensiveness to grief. e) Trust - Ranging from acceptance to admiration. f) Aversion / Disgust - ranging from boredom to loathing. g) Expectance / Anticipation - ranging from interest to vigilance. h) Surprise - Ranging from distraction to amazement. In the studies of Plutchik (2003), the author shows the deep studies of the theory of emotions proposed in 1980, a major review in the evolution of understanding of emotions.

\subsection{CONSUMER ATTITUDE AND PERSUASION IN ADVERTISING COMMUNICATION}

When investigating the use of rational and emotional arguments in the advertising messages of products and services, this article questions which one is more effective in shaping consumer attitude, which is considered as a predisposition to respond favourably or unfavourably to an object, according Gil-Saura and Ruiz-Molina (2008). This favourable response, derived from a process of persuasion, supported by rational or emotional arguments linked to the customer's value concepts, not only lies in the action of shopping, but also on customer loyalty: Gwinner et al (1998) explain that loyalty increases the sales volume of the company, and Payne and Frow (2005) complement that also reduces communication and attracting costs to new customers. In fact, the strategy of relationship marketing is aimed at searching, retention and loyalty of final and intermediate customers, remember Pizzinatto et al. (2005). Loyalty is defined by Gil-Saura and Ruiz-Molina (2008) as an attitude that sometimes involves the relationship with the brand. However, as attitudes, according to Wilkie, (1994), are learned, they are affected by information and experiences. A positive attitude towards a brand in youth can be changed to a negative attitude after an unsuccessful shopping or post-sale experience. Therefore, loyalty is a behaviour that is revealed after repeated purchases.

For these reasons, it can be noticed that people's attitudes vary according to several factors, including age, sex, income, personality that attach to brand their involvement with it, the country in which they reside. Studies by various authors on the attitudes of domestic purchasing of clothing products compared to buying abroad (BEAUDOIN et al, 1998; KAYNAK; KARA, 2002;. MOHAMAD et al, 2000) were focused on age of the consumer, analyzing changes in attitudes of young people in relation to mature age adults.

Regarding the brand personality, explain Guthrie and Kim (2009), it represents the set of human characteristics that describe a particular brand: is similar to the human personality, because consumers attribute human qualities to brands and often feel that they are involved with brands in a personal way. They describe the involvement as a state of motivation or 
arousal induced by rational or emotional factors to a product or brand. Regarding emotional factors, Lindstrom (2013) explains that "the brain tends to form mental shortcuts or markers (called somatic markers) that link aspects of the physical world to certain emotional states or conditions. The author claims to have found that companies intelligently manage to fix such somatic markers in the consumer's mind, "creating positive associations to a product or service". For example, the rewards and satisfaction that involve the use of the product. Also, that "we do not buy just an object, but also the concept that it represents." Thus, "if the implicit idea into a product or service is health, happiness, spiritual elevation and social responsibility," this is what will give an intense power to persuasion factors. In the case of luxury goods, the signs are of wealth, status and power, exemplify Phau and Leng (2008), quoting Bagwell and Bernheim (1996), Eastman et al., 1999; O'Cass and Frost, 2002; Vigneron and Johnson (1999).

In research on involvement, attitude and experience in online shopping, according to Caro et al (2011), the results showed that purchase intent over the Internet is directly influenced by the attitude and innovation, and the attitude is influenced by consumer involvement with the brand. Even if a consumer has no interest or previous involvement with it, the experiences offered by the brand can occur anywhere, their emotional reaction, concludes Pizzinatto (2013): "It is just one of the results caused by the experience, as well as attitudes and judgments about the brand are just a small part of what makes the whole experience with it."The brand experience, according to Brakus, Schmitt and Zarantonell (2009), can occur by simple exposure to attributes such as colors, designs, shapes, communication, slogans.

Therefore it is concluded that communication by means of rational or emotional arguments can cause experiences with the brand, helping to build, in the consumer's mind, positive or negative attitudes towards it, in influencing their decision making process and persuading them to buy or not certain product.

\subsection{RATIONAL APPEALS AS STRATEGY IN ADVERTISING}

Stern and Resnik (1977) developed a classification system for advertising based on rational content (informative), composing a list of 14 possible categories of useful information for the consumer. Thus, this model recommends matching the appeals to the attitude toward the product, that is, use informative advertising, i.e., based on rational appeals for products in which consumer attitude is predominantly cognitive. According to Stern and Resnik (1977), to be considered rational (informative), a notice must contain at least one of 
the 14 items. The fundamental principles of this perspective are twofold. First, advertising works to provide information about products that allow consumers to compare products on a price basis, leading to better economic aspects information in favour of the consumer. Second, informational advertising makes it possible the entry of new competitors. According to Man So (2004), the rational content (information content) is defined as the degree to which the publicity focuses on practical, functional or utilitarian needs of the consumer regarding the product. Receiving different levels of information, consumers can make smart purchasing decisions, choosing between different alternatives. Also according to the author, the additional information raises the level of awareness of customers regarding products or brands. The content providing information that differentiates a brand from its competitors tends to increase the process of remembrance understanding and persuasion. In short, the information content in advertising is an important influence on consumers in response to advertisements and brand awareness. (ABERNETHY; FRANKE, 1996). Still in the aspect of content, Resnik and Stern (1977, p. 51) recognize that in a very real sense, the information is "in the eye of the beholder", but note that an operational definition of content of reliable information can be useful for partnerships with advertisers, with the public and other stakeholders. Three major influences on rational advertising content have been examined in the literature: a) the medium carrying the advertisement, b) the country where the advertisement is placed, c) the category of the product being advertised.

According to Abernethy and Franke (1996), few studies have considered changes over time as an influence in the advertising content. According to the authors, contradictory evidence on the three influences were found, including:

- $\quad$ Print media allows messages of unlimited size and processing time, despite the limitation by fixed means of transmission and exposure, though that there is little evidence available regarding its efficiency when compared with the characteristics of the categories of print and broadcast media. Printed information is capable of carrying more information

- Crossed advertising practices are vital to global marketing. In the method developed by Resnik and Stern (1997) to measure advertising information, differences in levels of information between countries in general have been attributed to three major factors: regulation of advertising, influences, cultures and levels of economic development. 
- Works in several countries have failed to find a default rating for the product categories used.

\subsection{RATIONAL AND EMOTIONAL APPEALS IN THE CONTEXT OF ADVERTISING STRATEGY}

According to Russel and Lane (2005), information alone is not enough to respond to marketing problems. According to the authors, Jack Dempsey claimed: "By itself, information has no value." It acquires value when it has a purpose and relevance for marketing and advertising. Advertising motivates people by appealing to their problems, desires and goals and provides means of solving them. Consumers always have a craving for food, drink, comfort, safety, social value, power and success (RUSSEL; LANE, 2005, p. 482).

This leads to suggest that the two types of appeals can be used strategically. The advertising strategy is a set of decisions that translate into actions and help to achieve the goals set by advertisers on planned actions of marketing campaigns. The concept of advertising strategy can also be interpreted as a selective decision in the following method, in order to transform an advertiser's decision on a final communication to consumers (CARDOSO, 2009).

\section{METHODOLOGY}

Characterized as an exploratory study developed from secondary data (PIZZINATTO et al, 2012; MALHOTRA, 2006), i.e., those already published, this paper investigated 5.536 advertising of the top six female general interest magazines in circulation in Brazil (Nova, Claudia, Estilo, Elle, Marie Claire, Gloss), from May 2008 to August 2009. It was proposed to investigate the frequency of use by advertisers of various categories of products, and messages of rational and emotional content in advertising in women's magazines in Brazil.

The study of rational content was based on the model of content rating information of Resnik and Stern's (1977). To measure emotional appeals in women's magazines advertisements, the rating scale of emotion in advertising, based on the studies applied by Plutchik (1980), establishing 8(eight) items to the evaluation process was used.

Besides the scales, additional information to facilitate the process of analysis and data interpretation, including general category (durables, non-durables and services) and product categories were included in the tabulation of data. To interpret the data, it was used the SPSS 17 through frequency distribution, cross tabulations and correspondence analysis, to evaluate the scales and their statistical significance. (MALHOTRA, 2006; HAIR JUNIOR, 2005). Following, there are brief explanations about techniques of data analysis used. 


\subsection{CONTENT ANALYSIS}

Content analysis is an especially suitable research technique to carry out analyzes of objects linked to communication, in the words of Malhotra (2006, p. 201), notably advertising. By it, according to Cooper and Schindler (2003), it is measured the semantic content or appearance "what" of the message. According to the authors, other aspects of the methodology of content analysis include: selection of a sampling plan, registration instructions and coding, data reduction, inferences about the context, statistical analysis. The authors also argue that content analysis protects against selective perception of the content and ensures the implementation of reliability criteria.

In this investigation, the advertisings of each type were compared with the help of judges, from popular analysis techniques (KASSARJIAN, 1977). The advertisings were collected from magazines chosen in the mentioned period of 16 months. The goal was that, in all advertisings for the target audience, the work of identifying and coding the types of products, information content and emotion were made by at least three judges, previously trained. The methods of application of the classification systems established for this study, as well as the structure of the items of the scales of the authors, are described below.

\subsection{CLASSIFICATION SYSTEM OF RATIONAL APPEALS}

The application of this method of assessment focuses on the potential influence of the information contained in advertising and consumer perception, a relationship that has attracted, surprisingly, few studies in the academic literature. Resnik and Stern (1977) created a scale in order to facilitate the visualization of specific information, such as price and quality, which serve as clues that the general consumers can use to make smart choices and decisions among the various alternatives. This work shows a hierarchical model of the effects of advertising, ranging from content of advertising until analysis involving the results on attributes of perception and attitude (OLNEY et. al. 1991).

Based on the presence or absence of signals in the content of a message, this methodology involves attempts to assess the amount of information transmitted through the analysis of an advertisement. Studies such as those of Resnik and Stern (1991) and Abernethy and Franke (1996) have been published making use of this methodology in the analysis of messages in various media, including magazines, television and newspapers. The 14 criteria

for analyzing the rational contents of an advertisement had been proposed by Resnik and Stern (1977). According Albernethy and Frank (1996), the contents of the message contains at least one of the criteria, it is classified as an informational advertising. 


\subsection{MEASUREMENT UNITS}

According to Kassarjian (1977), this methodology to the content analysis establishes the classification and the classification of the present elements in certain communication stimuli. The coding helps the researcher to reduce thousands of answers to a few categories that contain the necessary information for analysis (COOPER; SCHINDLER, 2003). The items chosen for the process of appointment were: data from general category (goods or services) and product category. Representation by general category and product category is important in the process of entering data.

According to Man So (2004), this categorization helps to establish the interpretations between advertisings inserted in selected magazines and products involved. As for the definition of a general category, Ahmed (1996) apud Trinity (2008) suggests to establish the classification in Durable Goods, Non-Durable Goods and Services. The Durable goods are tangible goods, normally consumed for a longer period of time. Non Durable goods are tangible goods, normally consumed or used infrequently. Meanwhile, Services are intangible products, inseparable and perishable and require quality control and credibility.

\subsection{MEASURING UNIT OF CLASSIFICATION SYSTEMS}

The classification system of information developed by Resnik and Stern (1977) establishes a set of 14 items for ranking advertising based on informative content, presented in Table 1. It is highlighted the relationship of the items established in the proposal, as well as issues regarding each criterion. It is worth remembering that the scale was translated by the author from the article of Man So (2004). 
Table 1 - Classification System of Information (rational content)

\begin{tabular}{|c|c|}
\hline Criteria & Questions relating to the criterion \\
\hline 1. Price & $\begin{array}{ll}\checkmark & \text { How much does the product cost? What is its capacity to retain value? } \\
\checkmark & \text { What is its capacity for personal and financial satisfaction? }\end{array}$ \\
\hline 2. Components or Content & $\begin{array}{ll}\checkmark & \text { How is the product composed? What participants contains it? } \\
\checkmark & \text { What are the accessories included in the product? }\end{array}$ \\
\hline 3. Performance & $\begin{array}{ll}\checkmark & \text { How does the product work? Does it work well? } \\
\checkmark & \text { Comparing the alternatives, what does this product bring as differential? }\end{array}$ \\
\hline 4. Quality & $\begin{array}{l}\checkmark \text { What are the features of this product that differs it from the competition, } \\
\text { based on an objective assessment of its production (manufacture), } \\
\text { engineering, durability, excellence, structural superiority, personnel } \\
\text { superiority, attention to detail or special services? }\end{array}$ \\
\hline 5. Availability & $\begin{array}{ll}\checkmark & \text { Where product can be purchased? } \\
\checkmark & \text { When the product is available for purchase? } \\
\checkmark & \text { How can I get contact to purchase the product? } \\
\checkmark & \end{array}$ \\
\hline 6. Variety of Products & $\begin{array}{l}\checkmark \text { Affirmations for categories of products / services. Include varieties of } \\
\text { flavors, colors, sizes, styles or other characteristics. }\end{array}$ \\
\hline 7. Instructions for Use & $\checkmark \quad$ Statements regarding product use or alternative uses. \\
\hline 8. Special Offers & $\begin{array}{l}\checkmark \text { What approaches of limited-time promotion are available on a particular } \\
\text { purchase? }\end{array}$ \\
\hline $\begin{array}{l}9 . \quad \text { Packaging and } \\
\text { Appearance }\end{array}$ & $\begin{array}{l}\checkmark \quad \text { Does the product packaging make it more attractive than other } \\
\text { alternatives? } \\
\checkmark \quad \text { Are there different formats of this product available? }\end{array}$ \\
\hline 10. Warranty & $\checkmark \quad$ What post-purchase warranties accompanies the product? \\
\hline 11. Safety & $\begin{array}{l}\checkmark \text { Statements regarding safety of use features aimed to the consumer } \\
\text { regarding the product / service. This includes proper dosage and } \\
\text { warnings of use. }\end{array}$ \\
\hline 12. Nutrition & $\checkmark \quad$ Statements concerning nutrients or nutritional values in general. \\
\hline 13. Independent Research & $\begin{array}{l}\checkmark \text { Statements regarding the results of data collected by the company or } \\
\text { independent agencies considering its product characteristics, } \\
\text { performance or satisfaction }\end{array}$ \\
\hline 14. Competitive advantage & $\begin{array}{l}\checkmark \text { Statements regarding the advantage of the product over specific } \\
\text { competitive products. }\end{array}$ \\
\hline
\end{tabular}

Source: Man So (2004) - Translation of the scale by the authors

Further, Table 2 describes the classification system of emotion, composed of eight (8) items, proposed by Plutchik (1980), and issues related to the evaluation criteria of the scale. 
Table 2 - Emotional Appeals System Classification

\begin{tabular}{|c|c|}
\hline Criteria & Issues regarding the criterion \\
\hline$\checkmark \quad 1$ - Fear & $\checkmark \quad$ Ranging from apprehension to terror \\
\hline$\checkmark \quad 2$ - Anger & $\checkmark \quad$ Ranging from annoyance to rage. \\
\hline$\checkmark \quad 3-$ Joy & $\checkmark \quad$ Ranging from serenity to ecstasy. \\
\hline$\checkmark \quad$ 4-Sadness & $\checkmark \quad$ Ranging from pensiveness to grief. \\
\hline$\checkmark \quad 5$ - Trust & $\checkmark \quad$ Ranging from acceptance to admiration. \\
\hline$\checkmark \quad 6$ - Aversion / Disgust & $\checkmark \quad$ Ranging from boredom to loathing. \\
\hline$\checkmark \quad 7$-Expectance / Anticipation & $\checkmark \quad$ Ranging from interest to vigilance. \\
\hline$\checkmark \quad 8$-Surprise & $\checkmark \quad$ Ranging from distraction to amazement. \\
\hline
\end{tabular}
Source: Plutick (1980)

Apart from the scales proposed by the authors, Table 3 describes the other variables that composed the tabulation of the proposal advertisements sampling.

Table 3 - Classification of Categories, Brands and data from the advertisements

\begin{tabular}{|c|c|}
\hline CLASSIFICATION & UNIT OF MEASURE \\
\hline MAGAZINES & $\begin{array}{ll}1- & \text { Claudia } \\
\text { 2- } & \text { Nova } \\
\text { 3- } & \text { Elle } \\
\text { 4- } & \text { Estilo } \\
\text { 5- } & \text { Marie Claire } \\
\text { 6- } & \text { Gloss }\end{array}$ \\
\hline GENERAL CATEGORY & $\begin{array}{ll}\text { 1- } & \text { Durables } \\
\text { 2- } & \text { Non-durables } \\
\text { 3- } & \text { Services } \\
\end{array}$ \\
\hline PRODUCT CATEGORY & $\begin{array}{l}\text { 1- Food and drink } \\
\text { 2- Personal Care } \\
\text { 3- Recreation and Entertainment } \\
\text { 4- Home and Garden } \\
\text { 5- Clothing and accessories } \\
\text { 6- Telecommunications } \\
\text { 7- Furniture and utensils } \\
\text { 8- Vehicles and related } \\
\text { 9- Health and supplements } \\
\text { 10- Electronic products } \\
\text { 11- Travel and transportation Services } \\
\text { 12- Alcohol and tobacco } \\
\text { 13- Financial Services } \\
\text { 14- Education } \\
\text { 15- Real Estate } \\
\text { 16- Miscellaneous / varieties }\end{array}$ \\
\hline
\end{tabular}

Source: developed from the proposed survey.

\subsection{SAMPLING AND DATA COLLECTION}

The sampling process of content analysis is based on the theory proposed and defended by Malhotra (2001), which has as its starting point the definition and specification of the target population, that is, the elements that possess the information established by the researcher and over which it cannot be done any kind of judgment or inference. From the 
definition of the sample population, it was opted for the non-probability convenience sampling technique, that is, the units were chosen by the judgment of the author, highlighted that the results do not represent the total sample population.

According to Cooper and Schindler (2003), one can use the procedures of nonprobability sampling, i.e., if there is no desire or need to generalize a parameter of the population, there is less concern to know whether the sample reflects the population completely. According to the author, when sensory experiences consistently produce the same result, we can say that our data are reliable because they can be checked (COOPER; SCHINDLER, 2003). Pre-tests were performed on data tabulation, and all interpretation adjustments of the evaluation points must be set early in the process. The magazines chosen for the study are of monthly circulation. This circulation (volume of subscriptions + spare sales) follows as in Table 4.

Table 4- Average Circulation of the Sampled Female Interest Magazines

\begin{tabular}{ll}
\hline Magazines & \multicolumn{1}{l}{ Registered Circulation (2010 data) } \\
Claudia & 439 thousand \\
Nova & 235 thousand \\
Marie Claire & 216 thousand \\
Gloss & 156 thousand \\
Estilo & 135 thousand \\
Elle & 80 thousand \\
\hline Source: IVC - ANER (Associação Nacional dos Editores de Revistas*, 2010) \\
$*$ T. N.: (National Association of Magazine Publishers)
\end{tabular}

\subsection{RELIABILITY INDEX}

The reliability index analyzes the level of agreement among raters in applying the same set of items in the analysis of the same content, that is, it measures the degree of consistency among raters (ACEVEDO et al, 2006). High levels of disagreement may indicate flaws in the research technique. In this analysis, it was used the coefficient of correlation proposed by Karsajian (1977), which is the result of dividing the total number of agreements by the total number of observations. According to the author, for validity of the analysis, the reliability index or concordance between evaluators should exceed $85 \%$ and that values below this point tend to lose credibility.

There were 80 advertisements analyzed, already tabulated by the judges. Considering the total number of items and the sample, which totalled 2,320 notes, the number of identified differences was 72 or $3.1 \%$. This means that the degree of similarity and agreement in the 
interpretation of the data in the sample group was $96.9 \%$, that is, exceeds the minimum reliability index specified by Kassarjian (1977).

\subsection{CORRESPONDENCE ANALYSIS}

Hair Junior (2005, p. 441) defines the correspondence analysis (CA) as an important tool for perceptual mapping. The technique is based on the association between objects and a set of descriptive features or attributes specified by the researcher. Its application is to portray the matching variable category, which is established on the basis for the development of perceptual maps, which allowed the achievement of one of the major goals of this article, which is to identify the relationship between the characteristics of the magazine and the incidence of rational and emotional arguments, as well as the distribution of these arguments in relation to the general category and product category.

The term "perceptual mapping" used by Hair (2005), refers to a marketing technique, originally from the field of psychology, which assumes that consumers build an image of the product based on specific characteristics, such as benefits or prices. If studies can identify the characteristics of an ideal product for a given segment, perceptual mapping is an important variable for business opportunity and brand management. A simple cross-tabulation of multiple categorical variables can be represented in a perceptual space. It also allows the researcher to analyze existing answers or responses meet in least restrictive type of measure, the categorical or nominal level, even if only yes or no the type of answers, as is the case in this study. The CA is best suited to exploratory data analysis. (HAIR JUNIOR, 2005).

\section{PRESENTATION AND ANALYSIS OF RESULTS}

The results registered the proportions and the incidence of the scales of rational and emotional content on the advertisements of women's magazines published in Brazil, as well as the incidence of this content in general and specific product categories and distribution of magazines.

\subsection{FREQUENCY OF ADVERTISEMENTS IN MAGAZINES AND GENERAL AND PRODUCT CATEGORY}

The survey identified $24.3 \%$ of the advertisings on Claudia magazine (which registers on average monthly circulation of 439 thousand copies. This value is equivalent to the average monthly magazines Marie Claire and Nova (together, they point average circulation of 451 thousand copies). Justifications for the differences may be explained by the structure, the strategy of the magazines and other marketing aspects. Another important indication is 
that Marie Claire, Nova and Elle magazines feature a very similar incidence of advertisements, justifying the line representing each target audience.

Table 5 - Frequency of surveyed advertisements

\begin{tabular}{crc}
\hline Magazines & Frequency & $\%$ \\
\hline Claudia & 1.346 & $24,3 \%$ \\
Marie Claire & 984 & $17,8 \%$ \\
Nova & 977 & $17,6 \%$ \\
Elle & 935 & $16,9 \%$ \\
Estilo & 744 & $13,4 \%$ \\
Gloss & 550 & $9,9 \%$ \\
\hline TOTAL & 5.536 & $100,0 \%$ \\
\hline
\end{tabular}

Table 6 - Frequency of general category

\begin{tabular}{crc}
\hline Category & Frequency & $\%$ \\
\hline Non-durables & 4.286 & $77,4 \%$ \\
Durables & 538 & $9,7 \%$ \\
Services & 712 & $12,9 \%$ \\
\hline TOTAL & 5.536 & $100,0 \%$ \\
\hline
\end{tabular}

Source: elaborated from insertion and tabulation of data in SPSS

In the frequency of general category, the results indicate strong incidence of advertisements for nondurables, with $77.4 \%$ of the tabulated advertisements. The frequency of advertisements for services exceeds, even sensitively, the advertisements for durables. This may signal that the growth of the service sector in large metropolitan areas (IBGE, 2008) can justify the overlap on durable goods, characterized by the higher price ratio. The frequency of product category highlights that $67.3 \%$ of the ads are concentrated in the categories of Clothing and Accessories, with 37.5\%, and Personal Care with 29.8\%. Regarding the frequency distribution of these two important product categories and the magazines involved, the category Clothing and Accessories appears most evidently in Marie Claire magazine advertisings, 34.6\%, and the category of Personal Care, was observed in a higher frequency in Claudia magazine, with $24.4 \%$. 
Table 7 - Distribution of the frequency of advertisements per magazine

\begin{tabular}{|c|c|c|c|c|}
\hline Magazines & $\begin{array}{l}\text { Clothing and } \\
\text { Accessories }\end{array}$ & $\%$ & $\begin{array}{c}\text { Personal } \\
\text { Care }\end{array}$ & $\%$ \\
\hline Claudia & 255 & $14,4 \%$ & 402 & $24,4 \%$ \\
\hline Marie Claire & 613 & $34,6 \%$ & 186 & $11,3 \%$ \\
\hline Nova & 182 & $10,3 \%$ & 156 & $9,5 \%$ \\
\hline Elle & 251 & $14,1 \%$ & 175 & $10,6 \%$ \\
\hline Estilo & 242 & $13,6 \%$ & 349 & $21,2 \%$ \\
\hline Gloss & 231 & $13,0 \%$ & 380 & $23,1 \%$ \\
\hline TOTAL & 1.774 & $100,0 \%$ & 1.648 & $100,0 \%$ \\
\hline
\end{tabular}

\subsection{FREQUENCY OF EMOTIONAL AND RATIONAL CONTENT}

The tabulation of data on the scale of emotion indicated that the item joy / ecstasy (i.e., "the emotion can vary from serenity to ecstasy") was appointed in $63.5 \%$ of researched advertisings. The item trust / acceptance was identified in $25 \%$ of tabulated advertisements. In relation to the variables of surprise, fear, disgust, anger, were noted insignificant compared with the total sample of 5.536 advertisements tabulated by the judges.

Table 8 - Frequency - Emotional content

\begin{tabular}{|c|c|c|c|c|}
\hline \multirow[t]{2}{*}{ Variables } & \multicolumn{2}{|c|}{ Frequency } & \multicolumn{2}{|c|}{ Frequency (\%) } \\
\hline & yes & no & $\%$ yes & $\%$ no \\
\hline Joy / Ecstasy & 3.516 & 2.020 & $63,5 \%$ & $36,5 \%$ \\
\hline Trust / Acceptance & 1.383 & 4.153 & $25,0 \%$ & $75,0 \%$ \\
\hline Expectance / Interest & 364 & 5.172 & $6,6 \%$ & $93,4 \%$ \\
\hline Sadness / Grief & 315 & 5.221 & $5,7 \%$ & $94,3 \%$ \\
\hline Surprise & 100 & 5.436 & $1,8 \%$ & $98,2 \%$ \\
\hline Fear / Terror & 97 & 5.439 & $1,8 \%$ & $98,2 \%$ \\
\hline Aversion / Loathing & 56 & 5.480 & $1,0 \%$ & $99,0 \%$ \\
\hline Anger / Annoyance & 43 & 5.493 & $0,8 \%$ & $99,2 \%$ \\
\hline
\end{tabular}

Source: elaborated from insertion and tabulation of data in SPSS

The tabulation of rational content data indicated a fairly high frequency on the presence, in the advertisings, of the variable availability, accompanied by the also important issues of aspects related to the content / components and performance of products. It is worth noting that aspects such as price / value, safety and warranty were underrepresented, which raises important questions about the information content in magazine advertisings. 
Table 9 - Frequency - Rational content

\begin{tabular}{|c|c|c|c|c|}
\hline \multirow[t]{2}{*}{ Variables } & \multicolumn{2}{|c|}{ Frequency } & \multicolumn{2}{|c|}{ Frequency (\%) } \\
\hline & yes & no & $\%$ yes & $\%$ no \\
\hline Availability & 4.519 & 1.017 & $81,6 \%$ & $18,4 \%$ \\
\hline Components / Content & 2.232 & 3.304 & $40,3 \%$ & $59,7 \%$ \\
\hline Performance & 1.814 & 3.722 & $32,8 \%$ & $67,2 \%$ \\
\hline Variety of Products & 1.788 & 3.748 & $32,3 \%$ & $67,7 \%$ \\
\hline Quality & 913 & 4.623 & $16,5 \%$ & $83,5 \%$ \\
\hline Instructions for Use & 473 & 5.063 & $8,5 \%$ & $91,5 \%$ \\
\hline Packaging / Model & 439 & 5.097 & $7,9 \%$ & $92,1 \%$ \\
\hline Nutrition & 386 & 5.150 & $7,0 \%$ & $93,0 \%$ \\
\hline Special Offers & 382 & 5.154 & $6,9 \%$ & $93,1 \%$ \\
\hline Competitive advantage & 356 & 5.180 & $6,4 \%$ & $93,6 \%$ \\
\hline Price or Value & 229 & 5.307 & $4,1 \%$ & $95,9 \%$ \\
\hline Researchs & 212 & 5.324 & $3,8 \%$ & $96,2 \%$ \\
\hline Safety & 202 & 5.334 & $3,6 \%$ & $96,4 \%$ \\
\hline Warranty & 63 & 5.473 & $1,1 \%$ & $98,9 \%$ \\
\hline
\end{tabular}

Source: elaborated from insertion and tabulation of data in SPSS

\subsection{FREQUENCY AND PROPORTION OF RATIONAL AND EMOTIONAL ARGUMENTS}

For further information regarding the incidence and frequency of the items of the scales of rational and emotional content, the proportion in which items were mentioned in the sample of advertisements was assessed. Regarding the scale of rational content of the total sample were identified that $94.6 \%$ of the advertisements surveyed have "at least $1 "$ of the items in the content of the advertisings. On the scale of emotional content, it was indicated that $81 \%$ of the total sampled advertisements have "at least $1 "$ item of the scale.

Table 10 - Frequency of rational arguments

\begin{tabular}{crc}
\hline $\begin{array}{c}\text { No Itens p/ } \\
\text { Advertisement }\end{array}$ & Frequency & $\%$ \\
\hline 0 & 299 & $5,4 \%$ \\
1 & 1.677 & $30,3 \%$ \\
2 & 906 & $16,4 \%$ \\
3 & 1.265 & $22,9 \%$ \\
4 & 649 & $11,7 \%$ \\
5 & 447 & $8,1 \%$ \\
6 & 200 & $3,6 \%$ \\
7 & 64 & $1,2 \%$ \\
8 & 19 & $0,3 \%$ \\
9 & 9 & $0,2 \%$ \\
10 & 1 & $0,0 \%$ \\
\hline TOTAL & 5.536 & $100,0 \%$ \\
\hline
\end{tabular}


Table 11 - Proportion of rational arguments

\begin{tabular}{crc}
\hline $\begin{array}{c}\text { No Itens p/ } \\
\text { Advertisement }\end{array}$ & Frequency & $\%$ \\
\hline At least 1 & 5.236 & $94,6 \%$ \\
At least 2 & 3.560 & $64,3 \%$ \\
At least 3 & 2.654 & $47,9 \%$ \\
At least 4 & 1.389 & $25,1 \%$ \\
At least 5 & 740 & $13,4 \%$ \\
At least 6 & 293 & $5,3 \%$ \\
At least 7 & 93 & $1,7 \%$ \\
At least 8 & 29 & $0,5 \%$ \\
\hline
\end{tabular}

Source: elaborated from insertion and tabulation of data in SPSS

\subsection{FREQUENCIES OF RATIONAL AND EMOTIONAL ARGUMENTS - COMPARING} THE MEANS

There is a relatively wide variation in incidence of medium frequency of rational arguments between magazines. The same is not true regarding the emotional arguments, which distribution is more linear and balanced between magazines, as shown in Figure 2.

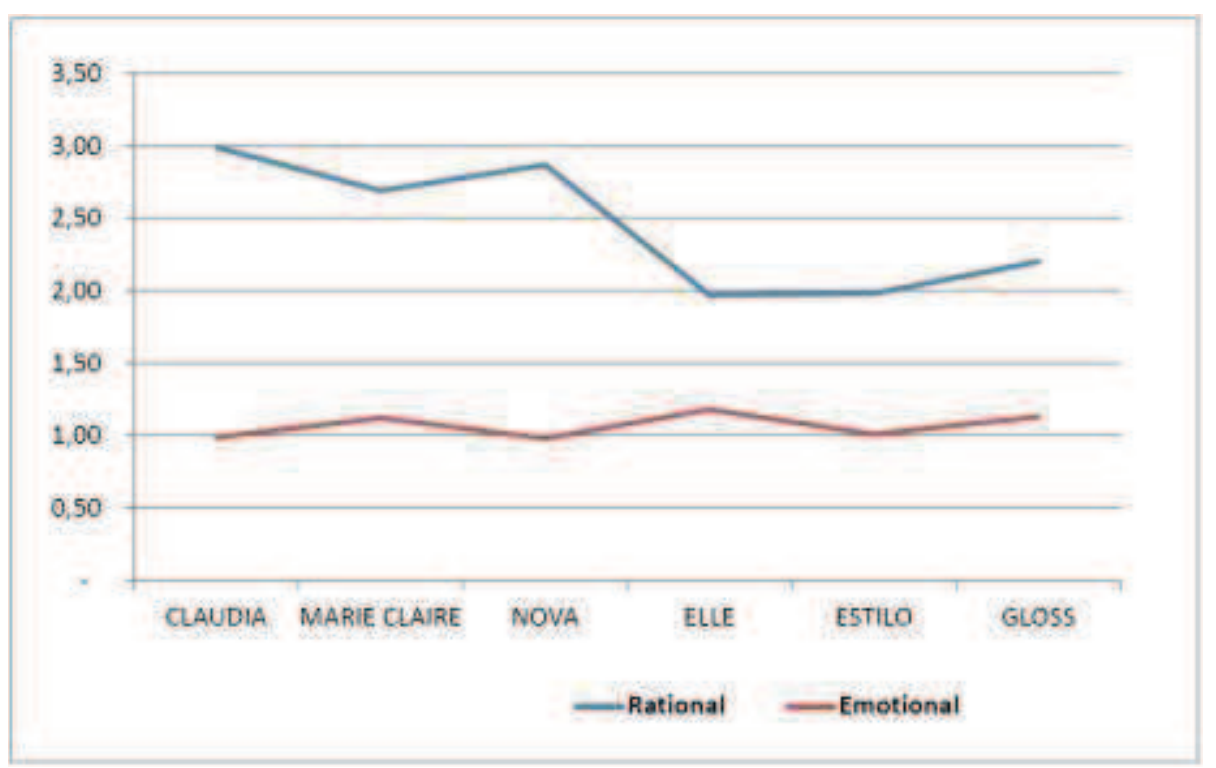

Figure 2 - Frequency of argument means between magazines

Source: elaborated from insertion and tabulation of data in SPSS.

The average number of items in the rational scale corresponds to a mean frequency ranging from 2.99 items in Claudia, to 1.97 in Elle. For comparison in relation to the items of the scale of emotion, calculation points to Claudia and Nova magazines with low mean of incidence of emotional items, that is, Claudia with 0.99 items per advertising and Nova, 0.98 items per advertising. In this evaluation, Elle shows the highest mean of incidence of emotional items per advertising, 1.18. The others showed stable mean. 


\subsection{CORRESPONDENCE ANALYSIS}

In the work of tabulation of the sample, the consolidation of incidence of the items of the rational and emotional arguments scales was made by creating three sub-variables: rational predominance (sum of the advertisements focusing only on information items), emotional predominance (sum of advertisements focusing only on items of emotion) and equality predominance (with the incidence of both arguments).

\subsection{THE CORRESPONDENCE OF MAGAZINE AND THE CATEGORY OF ARGUMENTS}

The analysis of the sample of advertisings points out the distribution of prevailing arguments, that is, advertisings on Claudia and Nova magazines feature predominantly rational characteristics, $78.6 \%$ and $74.9 \%$, respectively. The Elle, and Estilo magazines show absolutely equal frequency in $42.9 \%$ and a strong association of equal predominance. The Marie Claire magazine points to $64.1 \%$ of rational predominance and $24.4 \%$ of equality of arguments, and the Gloss magazine have a low incidence of rational dominance and $30.9 \%$ of the predominance of equality between the rational and emotional arguments. With the exception of Claudia and Nova magazines, rational and equality predominance is a common into all others, including in relation to Elle magazine, which has a strong focus on the predominance of emotional arguments, the order of $23.4 \%$.

The graphic of correspondence analysis between the variable magazine and the category of arguments, represented in Figure 3 illustrates the relationship of the magazine with its approach on either category. Elle magazine shows strong correspondence with emotional arguments. Advertisements on Nova, Marie Claire and Claudia magazines have strong correspondence to rational predominance, with Claudia and the Nova magazines with higher intensity than Marie Claire magazine. Among the magazines, the Estilo indicates individually a closer relationship with equal arguments, compared with the other magazines. For its part, the Gloss magazine is positioned between rational and equality predominance, but with greater proximity to the rational predominance. 


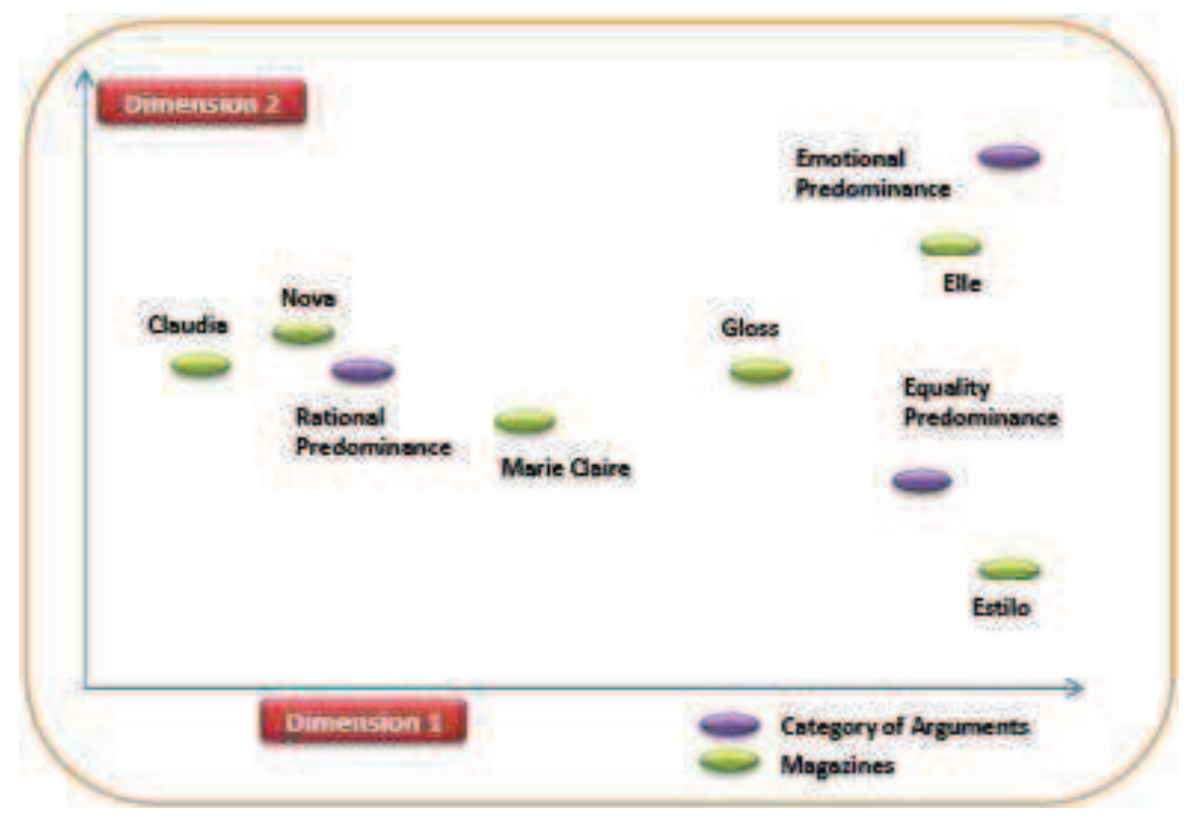

Figure 3- Correspondence between Category of Arguments and Magazines Source: elaborated from insertion and tabulation of data in SPSS.

\subsection{THE CORRESPONDENCE OF PRODUCT CATEGORY AND CATEGORY OF ARGUMENTS}

The rational predominance focuses on some important product categories such as: Personal Care, 73.2\%, Food And Drink, 77.1\%, Health and Supplements, 83.6\%, Vehicles, 89.2\%, Furniture and Utensils, 88.5\% and Electronics, 94.6\%. Concerning the arguments on an equal basis, the distribution is concentrated in the categories Clothes, $42.2 \%$, Recreation and Entertainment, 24.8\% and Education, 44.4\%. On emotional arguments, the product categories with the highest ratio correspond to Clothes, $21.8 \%$ and despite low ratios, it still appears on the categories Financial Services 10.0\%, Health and Supplements, 9.6\%, Home and Garden, 8.7\% and Personal Care, 8.2\%. Furthermore, the results indicate product categories such as: Food And Drink, Financial Services, Personal Care, Electronics, Furniture and Utensils with intense relationship with the category of rational arguments, as well as the category Clothing and Accessories with a similar relationship between the categories of emotional and equality arguments. The specific case of the Education category despite high relation with the arguments on an equal basis has low relation to the rational arguments, when compared to other categories.

\subsection{THE CORRESPONDENCE OF GENERAL CATEGORY AND CATEGORY OF ARGUMENTS}

The correspondence of general category (durables, nondurables, services) evaluates the prevalence of emotional and rational arguments. As already registered, the incidence of advertisements focused on advertising of durables is substantially larger than those of the 
other categories, 77.4\%. However, analysis of the sample indicates intense predominance ratio of nondurable and services with rational arguments. The predominant category indicates $57.2 \%$ incidence of rational arguments, equality with $28.3 \%$ and $14.5 \%$ to the frequency of emotional arguments. General categories of durables and services indicate a strong relationship with the incidence of rational arguments, $86.1 \%$ and $89.4 \%$, respectively.

The categories of durables and services have a strong correspondence with the rational predominance. Meanwhile, the category of nondurables is strongly linked to emotional and equality arguments category. Another important point is that the category of nondurables goods also has a similarity relation to the category of services in relation to the predominance of rational argument (Figure 4).

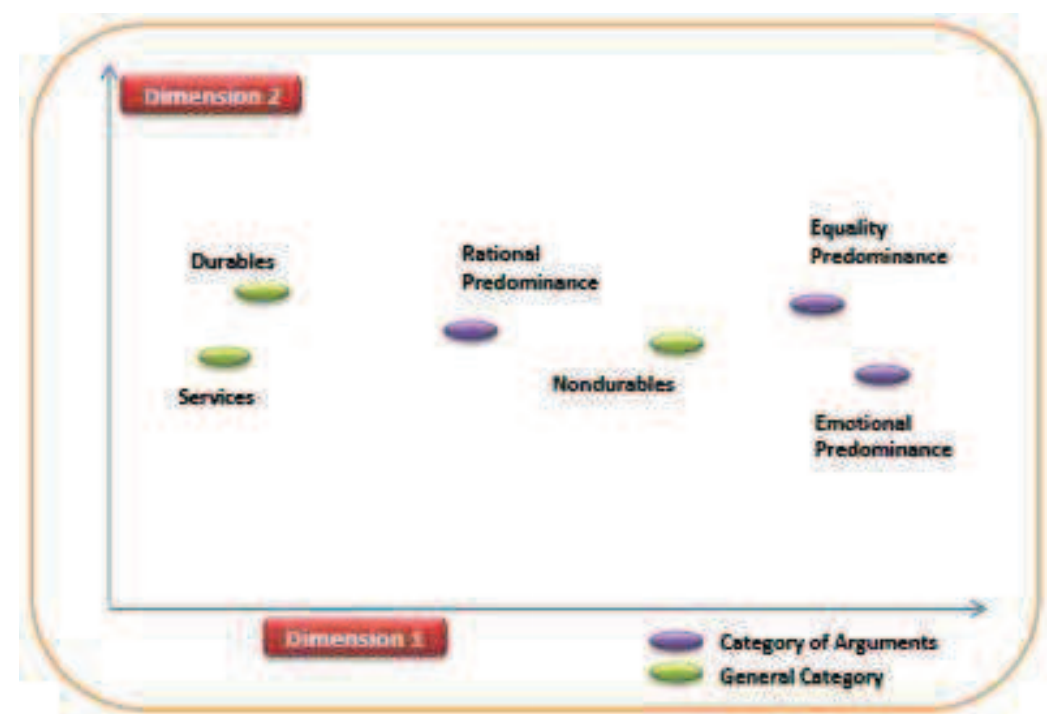

Figure 4- Correspondence between Category of Arguments and General Category Source: elaborated from insertion and tabulation of data in SPSS.

\section{FINAL CONSIDERATIONS}

Studies of rational and emotional content in consumption experiences represented an important research topic in the area of business communication, being very important for advertising, which is a business that the success is in knowing who the potential consumers and users are, what are their perspectives, needs and motivations. In short, it depends on the target's profile, which is, usually, the result of a complex network of influences based on the sociological, anthropological and psychological constructions of the individual, and explain by Russel and Verril (1986: 474). The authors complement that advertising rarely or never turns these influences, but rather channels its needs and desires to products and brands, mirroring the society, that is, the advertiser influences people by offering solution to their problems, not creating a needs ina an approach that is moving companies to invest heavily in 
targeting and advertising campaigns, seeing consumers as individuals, as opposed to large groups of buyers.

Also according to Russell, Lane and King (2005: 339-340), magazines can play a role both as the primary means for advertisers to reach potential consumers as a source of news, information and entertainment. This is the combination of prestige and segmentation that gives magazines a large qualitative advantage over most other media. The combination of reader in highly targeted advertising, editorial involvement and frequency between the various segments is of fundamental importance to the advantage of the magazines as a tool of marketing mix in the future.

Researches in the areas of marketing have sought to understand the emotional aspects involving consumers in relation to consumption of products or services. The scale of emotions used, proposed by Robert Plutchik (1980), is probably one of the most influential approaches to the general classification of emotional responses. After a period in which consumers were viewed as extremely rational decision makers based solely on attributes and benefits of the products, the several marketing scholars have proposed to study the emotions generated by stimuli, products and brands. (LAROS; STEENKAMP, 2005). The data presented in this study compared to advertisings with emotional content represent the belief from advertisers that it is possible to generate behaviours, motivations and actions of purchase from emotional stimuli.

In terms of incidence of rational arguments, the scale proposed by Stern and Resnik (1977) was used. Advertising with rational appeals motivates consumers through information and logical arguments. According to Man So (2004), information or rational content is defined as the degree in which the advertising focuses on practical, functional or utilitarian needs of the consumer for the product. In this study's case, by assuming rational arguments in advertisings for their products, advertisers believe that, receiving different levels of information, consumers can make smart purchasing decisions, choosing between different product alternatives, convinced by this kind of argument.

Correspondence analysis between magazines and the category of arguments pointed Elle magazine as one in which advertisers showed a strong correspondence with the use of emotional arguments. The Nova, Claudia and Marie Claire magazines showed strong correspondence with the predominance of advertisings with rational content, and Claudia and the Nova magazines with higher intensity than the Marie Claire magazine. The Estilo indicates individually a closer relationship with equal arguments, compared with the other 
magazines. In other words, advertisers are divided between those who rely on rational arguments and those who bet on the strength of emotional arguments. For its part, the inserted advertisements in Gloss magazine are positioned between the two predominance (rational and equality), but with greater proximity to the rational predominance, regarding the content of advertising.

Regarding the general category and the categories of arguments, the results indicate that the categories of durables and services showed a strong correspondence of the content of advertising with rational predominance. Meanwhile, the category of nondurable is strongly linked to the incidence of emotional arguments, but also equality, that is, it has the same number of items on the scale for both arguments. Another important point is that the content of advertising from the nondurable product category also has a relation of similarity to the category of services, in relation to the predominance of rational argument.

As for the product category and the relationship with the content of the arguments of advertisings, it can be emphasized the results of the product categories: Food And Drink, Financial Services, Personal Care, Electronics, Furniture and Utensils as those with intense relationship with rational arguments. Another important point is that the category Clothes showed a similar relationship between the categories of arguments of emotion and equality, which is to say that possesses an equal number of items in the scale for both arguments. The specific case is the Education category: although high relation with the emotional and rational arguments on an equal basis, it has, in relation to other categories, low relation with the rational arguments.

In summary, the distribution frequency of product category endorses the assumption that the characteristics of the magazines influence the higher incidence of certain types of advertisements. From the point of view of the frequency of rational and emotional arguments, the profile of the advertisements has a strong relationship with the general categories and products of the studied magazines.

Yet the results involving correspondence of arguments analysis with magazines and general and product category support the assumption that suggests that there is, in the view of advertisers, a relationship between the rational or emotional content with different targets of the magazines, as well as relationship with categories, both general and product. 


\subsection{ACADEMIC, METHODOLOGICAL AND EXECUTIVE CONTRIBUTIONS}

It is hoped that the results may facilitate the understanding of the effects and consequences of the research and that it might help marketing professionals to develop techniques and strategies of advertising in women's magazines advertisements. Based on this principle, is a contribution to the professionals in magazines and the advertising market follow the vision of advertisers of products aimed to a female audience on the consumption behaviour of this segment.

Were they correct in supposing that the rational or emotional arguments selected for the advertisings of a certain product is the one with more adherence to the scheme values of the female audience for that product category?

There are studies that suggest that there may be misconceptions about it: according to Machado (2010), women feel misunderstood by the companies, that is, companies are not yet prepared to meet the needs of that target audience, and have not adapted products for it. Few companies around the world are realizing the potential of this consumer segment of the population. Women want modernity, technology, design, but as long as it is combined with the necessities of rushing life between home and work, complete Marin (2010). And they expect, from companies, solutions that save their time.

All these benefits can be informed by advertising, with messages supported by rational and emotional appeals, according to the profile of the advertised product. For this, it is a must to use the correct argument content: Emotional or rational? Everything indicates that it depends, as already explained, on the concept of the product in the consumer's mind, their attitude towards it or its brand. The açaí sellers, exemplifies Lindstrom (2013), use emotional arguments to build the concept of a food product with therapeutic properties, using in the persuasion process, the somatic markers recommended by the author, selling this concept with the reward of health; however rely, advertisers, on rational arguments, citing research from the University of Florida (USA) as an evaluator of argumentation; moreover, it is also provided the concept of a cosmetic product, of anti aging action.

\subsection{SUGGESTIONS FOR FURTHER STUDIES}

This study, from the identification of the vision of advertisers on which advertisings arguments - rational or emotional - would be more effective to the female audience for different product categories, makes room for a continuation of scientific research. 
It was sought to contribute to the knowledge of Rational and Emotional Communication in Advertising in women's magazines in Brazil, both to deepen the academic knowledge in marketing as to scientifically back up the decisions of professionals involved in the management of promotional efforts and media planning.

The findings of this work allow to raise assumptions for carrying out further studies, linked, for example, to the investigation of how the product category influences the effectiveness of the type of appeal. For example, is it reliable to state that both, a product with the characteristics of açaí and to a luxury product, the emotional argument is the most effective? If so, which segment? Men and women were equally persuaded in their attitude towards a product or brand with the same type of argument? Wouldn't young people and adults have different attitudes towards certain products and or services and therefore would they be more persuaded by emotional or rational arguments?

All these questions suggest that there is room for conducting descriptive studies, survey type, along with several segments, to confirm or not the suitability of the profile option of the advertising from advertisers, allowing to check, for each product category, which would be in fact, the most effective content in the advertisings arguments: rational or emotional.

\section{REFERENCES}

ABERNETHY, Avery M.; FRANKE, George R. The information content of advertising: a meta-analysis. Journal of Advertising, June, 1996

ACEVEDO, C. R.; NOHARA, J. J.; BRACHEAR, T.; TAMASHIRO, H. How women are depicted in ads? A content analysis study with brazilian advertisements. International Business and Economic Research Journal, USA, v. 5, 2006.

BAGWELL, L.S.; BERNHEIM, B.D. Veblen effects in as theory of conspicuous consumption. The American Economic Review, v. 86, n. 3, p. 349-73, 1996.

BEAUDOIN, P., MOORE, M.A.; GOLDSMITH, R.E. Young fashion leaders' and followers' attitudes toward American and imported apparel. Journal of Product and Brand Management, v. 7, n. 3, p. 193-207, 1998.

BRAKUS, J.J.; SCHMITT, B.H.; ZARANTONELLO, L. Brand experience: what is this? how is this measured? Does it affect loyalty? Journal of Marketing, v. 73.2009

CARDOSO, P.R.. Os apelos racionais e emocionais na publicidade: uma analise conceptual. Universidade Fernando Pessoa, Portugal, 2009.

CARO,A. et al. Inovatividade, Envolvimento, Atitude e Experiência na Adoção da Compra

On-Line. RAE : Revista de Administração de Empresas, v. 51, n. 6, p. 568, 2005. 
CHIUSOLI, C. L.; PACANHAN, M. N.; LOPES, K. P. Comportamento do consumidor e as contribuições do modelo estímulo e resposta na orientação das ações de marketing: um estudo dirigido para produto de uso feminino. Disponível em: $<$ http://www.ead.fea.usp.br/Semead/7semead/paginas/artigos\%20recebidos/marketing/MKT2 1_Comportamento_consumidor_est_dirig_Prod.PDF>. Acesso em: 15 mar. 2009.

COOPER, Donald R.; SHINDLER, Pamela, S. Métodos de pesquisa em administração. 7 ed. Bookman, 2003.

DEL-VECHIO, R.; ANDRADE, D.; BRONEMANN, M.. O Sexo do consumo: a lucratividade está com elas um estudo sobre as diferenças comportamentais entre homens e mulheres na hora de consumir. In: CONGRESSO BRASILEIRO DE CIÊNCIAS DA COMUNICAÇÃO, 30., 2007, Santos (SP). Anais... Santos: CBCC, 2007.

EASTMAN, J. K.; GOLDSMITH, R. E.; FLYNN, L. R. Status consumption in consumer behavior: Scale development and validation. Journal of Marketing Theory and Practice, v. 7, n. 3, p. 41-52, 1999.

GIL-SAURA, I; RUIZ-MOLINA, M. E. Perceived value, customer attitude and loyalty in retailing. Journal of Retail \& Leisure Property, v. 7, n. 4, p. 305-314, 2008.

MEYER, Carolina; ARAGÃO, Mariana . O maior mercado emergente do mundo: o maior dos mercados emergentes. EXAME, Ed. 0968, p. 18-30, 2010.

FRAGA, H. C. S; SERRALVO, F. A. Fatores determinantes do comportamento do consumidor feminino: o caso American Girl. Gesta. Gestão de Negócios, v. 2, n. 1, 2006.

GUTHRIE, M. F.; KIM, H.-S. The relationship between consumer involvement and brand perceptions of female cosmetic consumers. Brand Management, v. 17, n. 2, p. 114$133,2009$.

GWINNER, K. P.; GREMLER, D. D.; BITNER, M. J. Relational benefits in services industries: the customer's perspective. Journal of the Academy of Marketing Science, v. 26, n. 2, p. $101-114,1988$.

HAIR, JUNIOR F. et al. Análise multivariada de dados. Porto alegre: Bookman, 2005. Multivariate data analysis. 5 ed. New York: Macmillan, 1998.

HAWKINS, D. L.; MOTHERSBAUGH, D. L.; BEST, R. J. Comportamento do consumidor: construindo a estratégia de marketing. 10 ed. São Paulo: Campus, 2007.

IVC. Instituto Verificador de Circulação. Órgão de avaliação de circulação de revistas no Brasil.

JORGE, A. R. Publicação Revistas com Estilo. Revista JJ, Lisboa, jul/set, p. 24-29, 2008.

KAYNAK, E.; KARA, A. Consumer perceptions of foreign products: an analysis of productcountry images and ethnocentrism. European Journal of Marketing, v. 36, n. 7/8, p. 92849, 2002. 
KASSARJIAN, H. Content analysis in consumer research. Journal of Consumer Research, v. 4, n. 1, 1977.

LAROS, Fleur J.M.; STEENKAMP, Jan-Benedict E.M. Emotions in consumer behavior: a hierarchical approach. Journal of Business Research, 2005.

LINDSTROM, M. Brandwashed: o lado oculto do marketing. São Paulo: HSM Editora, 2013.

MACHADO, M. A - Professor Marketing e Planejamento Estratégico - Ibmec, 2010 Record OnLine, Economia e Negócios. Março/2010

MALANGA, E. Publicidade: uma introdução. São Paulo: Atlas, 1979, 2008.

MALHOTRA, N. K. Pesquisa de marketing: uma orientação aplicada. Porto Alegre: Bookman, 2006. 2001.

Pesquisa de marketing: uma orientação aplicada. 3. ed. Porto Alegre: Bookman,

MAN SO, S. L. A Comparative content analysis of women's magazine advertisements from hong kong and australia on advertising expressions. Journal of Current Issues and Research in Advertising, v. 26, n. 1, 2004.

MARIN, E. R. Comunicação racional e emocional na publicidade em revistas femininas no Brasil. 2010. 203 f. Dissertação (Mestrado) - Programa de Pós-Graduação em Administração da Universidade Nove de Julho (UNINOVE), 2010.

MOHAMAD, O. et al. Does 'made in'matter to consumers? A Malaysian study of country of origin effect. Multinational Business Review, v. 8, n. 2, p. 69-74, 2000.

O'CASS, A.; LIM, K. Consumer brand classifications: an assessment of culture-of-origin versus country-of-origin. The Journal of Product \& Brand Management, v. 10, n. 2, p. 120-41, 2001.

OLNEY, T. J.; HOLBROOK, M. B.; BATRA, R. Consumer responses to advertising the effects of ad content emotions, and attitude toward the ad on viewing time. Journal Consumer Research, 1991.

PADUAN, R.; HERZOG, A. L. Para entender a Classe C. EXAME, Ed. 0940, Ano 42, p. 22-30/32-39, 08 abr. 2008.

PAYNE, A.; FROW, P. A strategic framework for customer relationship management. Journal of Marketing, v. 69, n. 4, p. 167-176, 2005.

PHAU , I. ; LENG, Y. S. Attitudes toward domestic and foreign luxury brand apparel A comparison between status and non status seeking teenagers. Journal of Fashion Marketing and Management, v. 12, n. 1, p. 68-89, 2008.

PIZZINATTO, N. K. et al. Marketing focado na cadeia de clientes. São Paulo: Atlas, 2005. Pesquisa pura e aplicada para marketing. São Paulo: Atlas, 2012. 
PIZZINATTO, A. Fatores de avaliação de marca: um estudo experimental no mercado de luxo. 2013. Tese (Doutorado) - Programa de Mestrado e Doutorado em Administração da Universidade Nove de Julho (UNINOVE), São Paulo, 2013.

PLUTCHIK, R. A general psychoevolutionary theory of emotion. In: PLUTCHIK, R.

PLUTCHIK, R. Emotions and life: perspectives from psychology, biology, and evolution. Washington, DC: American Psychological Association, 2003.

Emotion: a psychoevolutionary synthesis. New York: harper \& Row, 1980.

RESNIK, A.; STERN, B. An Analysis of Information Content in Television Advertising. Journal of Marketing, Jan, 1977.

;. An analysis of information content in television advertising. Journal of

Marketing, v. 41, n. 1, 1977.

RUSSO, C.; TROIANO, J. Beauty and the beast: how brands bridge the two sides of women's personality. 2008

SHETH, J. N.; MITTAL, B.; NEWMAN, B. L. Comportamento do cliente: indo além do comportamento do consumidor. São Paulo: Atlas, 2001.

SHIMP, T. Propaganda e promoção: aspectos complementares da comunicação integrada de marketing. Porto Alegre: Bookman, 2002.

SOLOMON, M. R. Comportamento do consumidor: comprando, possuindo e sendo. 5. Ed. São Paulo: Bookman, 2002.

STERN, B. L.; KRUGMAN, D. M.; RESNIK, A. Magazine Advertising: An Analysis of Its Information Content. Journal of Advertising Research, v. 21, n. 2, 1981.

STERN, B. L.; KRUGMAN, D. M. Are magazine advertisements informative? An analysis of information content of magazine advertising. In: Proceedings of the 1980, James E. Haefner, ed., Champaign, IL: American Academy of Advertising, 1980.

VIGNERON, F.; JOHNSON, L. W. A review and a conceptual framework of prestigeseeking consumer behavior. Academy of Marketing Science Review, p. 1-15, 1999.

XAVIER, I. A imagem das marcas. São Paulo: Companhia das Letras, 1998. 